\author{
Khlystun Olena \\ Ph.D. in Art Studies, Associate Professor, \\ Chair of show business \\ Kyiv National University of Culture and Arts, \\ with_joy@ukr.net \\ ORCID 0000-0002-1764-6559
}

\title{
GLOBALIZATION PROBLEMS OF THE SUBJECTIVE CULTURAL MEASUREMENT IN THE SPACE OF THE COMMUNICATIVE ENVIRONMENT: HOMO ESTETICOS AS THE EPICENTER OF THE HARMONIZATION OF THE ESSENCE
}

The purpose of the article is to determine the cultural and aesthetic problems of the formation of a communicative environment as a factor in the harmonization of the globalization problems of our time. Methodology. The methodological basis of the study is the dialectical principle of cognition, systemic, sociocultural, historical approaches, fundamental provisions of the theory and history of culture. Common scientific and interdisciplinary research methods are used: analysis and synthesis, induction and deduction, comparison, generalization, formalization. The scientific novelty of the results is to identify the key problems of perceiving the subjective dimension of culture in the space of the modern communicative environment. Conclusions. The aesthetic-ecological dimension of cultivating and communicating provides an opportunity to move away from excessive metaphors and see the culture in its constitutive subjective principles of human identity. It is noted that the categorical list of descriptions of the perception of the aesthetic environment cannot be purely psychological, it is not an instrumental means of feeling the harmony of the substance. Thus, the lifelike creative stream that permanently updates the planet, man and its non-aggressive activity, amateur activities translate the aggressive element of the interaction of actors of globalization processes into a phase of harmonious unification of efforts. Aesthetic images of selfdetermination on the brink of their implementation require to play as a substantive leak when the game plays in people as a harmonizing turn of the essence.

Key words: Communicative environment; ethos; aesthetic values; meta-ecological reflection; cultural practices.

Хлистун Олена Сергіївна, кандидат мистецтвознавства, доцент Київського національного університету культури і мистеите

Глобалізаційні проблеми суб'єктного виміру культури в просторі комунікативного середовища: homo esteticos як епіцентр гармонізації сутнього

Мета роботи - визначити культурологічні та естетичні проблеми формування комунікативного середовища як фактора гармонізації глобалізаційних проблем сучасності. Методологічною основою дослідження є діалектичний принцип пізнання, системний, соціокультурний, історичний підходи, фундаментальні положення теорії й історії культури. Використано загальнонаукові й міждисциплінарні методи дослідження: аналіз і синтез, індукція і дедукція, порівняння, узагальнення, формалізація. Наукова новизна одержаних результатів полягає у виявленні ключових проблем сприйняття суб'єктивного виміру культури в просторі сучасного комунікативного середовища. Висновки. Естетично-екологічний вимір культуротворення та комунікації надає можливість відійти від зайвого метафоризму та побачити культуру в її конституативних суб'єктних засадах ідентичності людини. Відзначено, що категоріальна партитура опису сприйняття естетичного середовища не може бути суто психологічною, вона не $€$ інструментальним засобом відчуття гармонії сутнього. Таким чином, животворний креативний потік, що вічно оновлює планету, людину та її неагресивна активність, самодіяльності переводять агресивну стихію взаємодії акторів глобалізаційних процесів у фазу гармонійного єднання зусиль. Естетичні образи самодетермінації на межі свого здійснення потребують гри як субстантивного витоку, коли гра грає в людях як гармонізуючий виток сутнього.

Ключові слова: комунікативне середовище; етос; естетичні цінності; метаекологічна рефлексія; культурні практики.

Хлистун Елена Сергеевна, кандидат искусствоведения, доцент Киевского национального университета культуры и искусств

Глобализационные проблемы субъектного измерения культуры в пространстве коммуникативной среды: homo esteticos как эпицентр гармонизации сущего

Цель работы - определить культурологические и эстетические проблемы формирования коммуникативной среды как фрактора гармонизации глобализационных проблем современности. Методологической основой исследования является диалектический принцип познания, системный, социокультурный, исторический подходы, фуундаментальные положения теории и истории культуры. Использованы общенаучные и междисциплинарные методы исследования: анализ и синтез, индукция и дедукция, сравнение, обобщение, формализация. Научная новизна исследования заключается в выявлении ключевых проблем восприятия субъективного измерения культуры в пространстве современной коммуникативного среды. Выводы. Эстетико-экологическое измерение культуротворения и коммуникации дает возможность отойти от лишнего метафоризма и увидеть культуру в ее конституативних субъектных основах идентичности человека. Отмечено, что категориальная партитура описания восприятия эстетической среды не может быть чисто психологической, она не является инструментальным средством ощущение гармонии сущего. Таким образом, животворящий креативный поток вечно обновляет планету, человека и его неагрессивная активность, самодеятельности переводят агрессивную стихию взаимодействия актеров глобализационных процессов в фазу гармоничного единения усилий. Эстетические образы самодетерминации на грани своего осуществления требуют игры как субстантивного истока, когда игра играет в людях как гармонизирующий исток сущего.

Ключевые слова: коммуникативная среда; этос; эстетические ценности; метаэкологическая рефлексияж культурные практики.

Introduction. The problem of cultural globalization is closely linked to the definition of identity, unique culture. This sociological approach characterizes the institutional approach to identify individuals - actors of globalization, as yet defines the mechanisms of globalization as well. Often these mechanisms are linked to the growing complexity of technology and the universalization of communication. After all - it's the superficial approach. Z. Bauman writes: "The problem that plagues people at the end of the century consists of not only how to find the chosen identity and force others to accept it, but which identity to choose if you had chosen the identity that loses value over time. The main and most nervous problem is how to find their place in the

(C) Khlystun O., 2019 
rigid frames of class and, if found, save it and avoid expulsion. Human is irritated by the suspicion that the frames in which it was so hard to pull yourself into, quickly collapse or disappear completely" [1].

Analysis of publications and studies. The problem of globalization culture was studied in the works of Z. Bauman, Vladimir Malakhov, J. Urri, Chornenka N. et al. $[1 ; 4 ; 7 ; 9]$, as defined by important philosophical and anthropological aspects of the aesthetic and cultural environment in the space of cultural globalization.

The purpose of the article - identify cultural and aesthetic problems of the communicative environment as a factor in harmonizing globalization challenges.

Main part. Identity cultures in their "passionate" phase defined in modern society as multiculturalism. There are formed adaptive-type synergistic coexistence of cultural colonies on the rights of ethnic identification. In fact, as a type of human culture, integrity is unified and reduced to ethnic and cultural populations. B. Markov writes: "A typical city of the world today is New York. Because if you look at it's the most crowded place - the center where young people are hanging out. Seeing this, the thoughtful observer dives into deep sorrow. On the one hand, this creates the peaceful coexistence of whites and blacks, Italians and Jews, Chinese and Hispanics. This achievement seems to emulate the good old traditions of America. As we know, it was colonized by different peoples, forced to live in a world in peace, to find some new forms of identification, free of national or racial limitations.

In addition to the variety of colors and types of traditional clothing, we can see fascinating diversity in entertainment" [5, 180-181].

Multifaceted culture, as well as multiculturism - a fertile field for homogenization, as happened in North America. However, this model cant is universal, since it turns into open colonialism of cultural expansion. To understand the logic of identifying locuses, let's turn to cultural studies. Fedotov, V. Kolpakov, N.Fedotova:

"- the ratio of past and new identities where they form, does not depend on their number, but there is the definite integral of the individual, community, corporation or country. In this case, it is difficult to talk about multi-identity while multiculturalism is still quite possible;

- Multi-identity is possible to form, but it creates the essence of identity problem (S. Huntington);

- Multi-identity is formed; therefore, the identity problem is resolved by itself. Sometimes this serves as a proof that identity doesn't matter that much today.

Problems escalate into a crisis if between different interpretations of the meaning there is no certain intersection" [8, 397].

But the concept of "multi-identity" is an oxymoron, a sort of "schizophrenia" as G. Deleuze and F.Guattari said. This is convenient for the manipulative actions of cultural enclaves. Thus, the problem in Ukraine today can be described as "polyethism" because sometimes ethnic enclaves comprise of no more than ten representatives. Thus, the sociological approach is not universal. The paradigm of meta-ecological aesthetics allows to avoid schematics, homogenization and show the real mechanisms of the culture globalization. In our view, the mediating area of cultural integration is a state of constitutive principle in culture creation, and it's a field of aesthetic institution reflection.

It is important to note that globalization is not a part of modern cultural heritage and is formed as extensive metric colonization, adaptation, an association of cultures due to the spread of world religions, the development of civilization in general. D. Held, E. MakHryu D. Goldblatt D. Perraton said: "It is ironic that none of the traditional world religions - Christianity, Islam, Confucianism, Hinduism, Judaism, and Buddhism - is not common in a big way, or not spread on the specific continent or region, while Christianity and Judaism have supporters in most corners of the globe, Buddhism and Confucianism tightly focused in their regional areas: South Asia, East Asia, and China. Islam occupies an intermediate position - being assertive represented in the Middle East and North Africa and with their co-religionists in the rest of Africa and Asia. Of course, these religions have small and quite numerous migration groups in quite unexpected places: 1 million of Shinto followers in Brazil, 4 million of Turkey-German Muslims at the center of Christian Europe; Goan Catholic enclave on the west coast of India. World religion is essentially determined post hos (as a matter of fact - Lat.) After religion are considered as "global," their scale increase in the number of followers beyond their places of origin" [2, with. 390-391].

Thus, the missionary role of religion has always relied on patterns, gestalts deity, morals, the political absolute aesthetic of synthetic type reality. This mechanism continues to exist even now because, in a different context, where there is a domination of business, sociopragmatics, global corporations, and others, mass culture industry generates an identification of new formats of images, aspirations, motivation and behavior. TV space, media, pop music and general youth culture of hip-hop (rap, rave culture, rock culture, etc.) form a spectacular culture that has differentiated the artistic practices and forms its aesthetic.

Art and public forms of communication not only complement each other, but also reflect and mirror the overall aesthetic intentions of the planet; they are the two parts of the world's mental body that lives on forever. Meta-ecological aesthetics of human communication environment can be imagined in two dimensions: macro (as the dialogue of cultures in space and time) and micro (regional reception as national cultures and their development). The utopianism of global projects requires harmonization, which is commensurate to the extensive metric of colonization others by one civilization. Religious space with its fundamentalism 
does not already help. The only thing that remains is the basic culture space. The main subject of this space is Homo Normalis, which is universal to all humanity organic needs.

The strategy of alter-globalization as a broad perspective of the use of all resources is the only one left possible. The concept of harmonization of "sustainable development" is the only one possible as well. Basically, starting with the culture, rather than inequality and economic ills. Only a few have the hope that following the economic way of Westernization, modernization, transformation model we can stop the local wars, calm down the geopolitical ambition and other things. However, the Club of Rome forecasts, the negation of "the empire of human", by A. Peccei, haven't educated the globalization theorists of the West. Even more difficult challenges of cultural globalization can be found in post-Soviet countries.

Modernization serves as a transit of Western values, the projection of Western models of development in the cultural space of the former USSR looks like a fake. O. Motyl asks: "What conclusions can follow from the pessimistic analysis of Ukraine and other post-communist countries? First, with almost complete certainty we can confirm that the transformation of Ukraine, Russia, and other former Soviet states has ended. Over the past ten years in most post-Soviet countries a stable political and economic system were introduced. They are neither communist nor capitalist, totalitarian, democratic. Markets are poorly developed; democracy is nothing more than a fancy word, blurred national identity and the law is entirely fictitious instead, political and economic power in the hands of clans, the regional elite society, the parasitic bureaucracy which reigns over the president's semi-authoritarian" [6, 36].

Dialogue about the help of the IMF becomes permanent colonization and endless struggle of political elites to lead the country to the collapse of indigenous capitalism that never really gave any growth, nor the new ideals of national culture. Development models of "Westernization" and "Keeping up" work as the principles of Western reception. V. Fedotov, V. Kolpakov, N. Fedotov wrote: "Westernization - is the transition from traditional to modern society by the direct transfer of the structures, technologies, and lifestyle of Western societies. Note that Westernization differs as a model of modernization and as part of any other model. It links western connections, which are always necessary for modernization. The initiator of Westernization is usually the West itself. Usually, the method of such modernization is colonization."[8, 100].

Gabriel Marcel said that wisdom is the measurement of life right now. The realization of this comes only when we face the threat of war, hyperinflation and other horrors destined to a human. "Sofiynist" as the generative principle of meta-ecological aesthetic holds the vertical axis of the intensive metric of the culture creation, which connects the contemplative and aesthetic strategies in the area of "limited acts" Eastern model. Yes, Japan has stopped the transit of Western technology and suspended the upgrade of the technical and technological complex. Homeostasis of this nature for traditional culture made to stay further away from the temptations of Westernization and modernization.

Sofine understanding of human destiny, human beauty, and creativity are that proportionality creative intentions define the context of today's science, art, and culture in general. Yes, the creation of myths is making a comeback, combining human life with wonders. Life is a miracle, mystery of co-existence, as M.Bakhtin said, it can not be described in values, ideology, culture or any other logistic structures.

Equally important is the category of "experience" as a reflective archive of corporate and any other conscious. All these categories are not without a simulation game and the temporal dimension of being appointed. The reality without a game like feeling loses a lot in aesthetics, and a human does not want to accept such categories as "system", "value" and others without this feeling. Moreover, after an anti-value explosion within the Marxist methodology in the aesthetics of V. Ivanov, the reaction occurred and its transcendentality. Again and again, we can hear that the value is the foundation on which aesthetic is based. Object measurement in aesthetics as a system of norms and measurements seems unshakable.

But in environmentally-planetary terms, we understand that, if thinking within the subject-object paradigm, activities or values can be considered as an anachronism. If we begin to examine the phenomenon of aesthetic as "setting a goal of no goals" (this is a brilliant interpretation of Kant), like a game of eternal topos of personal space where forever young creative producers create a perspective for themselves, then the division into two worlds (material and ideal, economic and ideological et al.) is not enough. Not ambivalence, but multivalency is needed to see the prospect of a harmonious eco-future.

So vivifying creative flow that always updates the planet and the human. This non-aggressive activity is transferring the aggressive interactions of globalization actors into a phase of the harmonious unity of effort. Aesthetic self-images, on the verge of its implementation, are in need of game as a substantive leak, because when the game is played in people as harmonizing the relativity of being round. If the game gets the creative significance, juvenile and regenerating measurement of cultural institutions of the planet and human, then this game cannot be considered as a "game" at all in natural or purely manipulative kind, to which we are used to.

The game as a regenerative mechanism of permanent promotion of the young people to their new word in fashion, for example, cultivated as well as a mechanism for cultural creation. Thus, the youth culture of the Renaissance, Classicism youth, Modernism and Postmodernism youth are invariant, as shown by O.Spengler. All this shows that wisdom in the arms of youth is not a tragedy, as Gabriel Marcel said. This is the eternal wisdom of development, and all that you need to do is not shorten, but extend the life of the planet and humans. 
For personal, cultural or meta-cultural and transpersonal measurement, there is another transcendental term, which is also making a comeback today. It's faith. Faith as a phenomenon of mind, decision making, and others. Faith cant is explained by the casual set of goal-setting or activities. This is increasingly the person's ability for contemplation, ability to create and accept a miracle in front of God. Faith is the anticipation of transcendental reverence in front of the rest of the world that is dissolved in the arms of the game. However, it is not a modern online video games world, but the substantial world - the substance of game and faith deploying culture perspectives. The game "triggers" the force of cultural creativity, because their faith defines them and fills the goal with a sense, reflects the beauty of moral values.

Faith is possible when there is a distancing, as M. Buber said, as a proportion with the Absolute. But the ability for subject to overcome the distance is attributed in other things, which have different faces and different names. We will not create a list of these names and faces, because we will go beyond our topic.

It is important to say that without the gaming element of contemplation, which is mentioned by M.Bakhtin, a sacred existence of a human in the world is impossible. Human existence is all about being unique, intimate and self-sufficient. This place is a topos of creation, which begins with the growth and dynamics of values.

Faith as an aesthetic category is not designed, nor sung as a reflection of contemporary environmental aesthetics. Faith is the person's ability to stop and do not play, but only observe the game with their intrinsic power of the essential forces of the universe. All this shows that faith is a transcendental meta-ecological aesthetic category, enabling people to talk about the aesthetic of human as the epicenter of overall harmonization.

This is the aesthetic of excess self-sufficiency of human in the world, perfectly described by M. Bakhtin. In this context, it is important to define the aesthetic by the sample as a self-sufficient object of aesthetic reflection that needs no explanation. So O. Losev synthesized Kant's transcendentalism (brought him to apophaticism) and notational phenomenology (worked on dialects notational space constitution and elaborated its category as "fact"). This transcendental-phenomenological directed aesthetic Universum from O.Losev described purely apophatic such topics as "name", "energy," etc., where he looks at aesthetic as self-sufficient integrity act.

O. Losev in his article "The dialectic of the creative act" wrote: "To imagine the creative act as some kind of logical structure, after being distracted by others, more vital, more full of tests (psychologically and even personally, socially, political y and even historically) it is necessary to take the path of various kinds and finding everything that is not described in the scientific images of the creative process. All of these definitions and destinations at first glance may seem superfluous to understand creativity. But this kind of "first look" is based on ignoring the logical structures" $[3,48]$. So instead of Marxist "aesthetic attitude" as the postulated sphere of aesthetic, the manifestation of "act" as self-giving world of beauty, tragedy, comedy and other aesthetic categories.

Scientific novelty consists in the use of the main globalization problems of the subjective measurement of culture in the space of the communicative environment, by determining the meta-ecological aesthetics of the communicative environment of man in two dimensions: at the macro level (as the dialogue of cultures in space and time) and at the micro level (as the regional reception of national cultures in relation to own development).

Conclusions. Self-sufficiency of aesthetic integrity is in some way mythological and Christianized as "prototype." A. Losev in the "Dialectics of Myth" called this a miracle and joy of eternal life, enjoying the meeting of different entities, getting pleasure from this discovery. In his 12 theses about the antiquity, he speaks of eternal youth of science, although we also understand that behind the science there is an eternal young cosmos "hiding" ancient and eternally young Greeks aesthetic sense. Losivski intentions lead to a synthetic "polystylistic" thinking in aesthetics and philosophy as a whole.

\section{תimepamypa}

1. Бауман 3. Идентичность в глобализирующемся мире. 2005. URL : http://www.lovievich.ru

2. Гелд Д., МакГрю Е., Голдблатт Д., Перратон Д. Глобальні трансформації. Пер. з англ. В. Курганський, В. Сікора. Київ : Фенікс, 2003. 548 с.

3. Лосев А. Диалектика творческого акта (краткий очерк) // Контекст 1981. Москва: Наука, 1982. С. 48-78.

4. Малахов В .А. Етика. Київ : Либідь, 2001. 384 с.

5. Марков Б. В. Храм и рынок. Санкт-Петербург : Алетейя. 1999. 295 с.

6. Мотиль О. Україна в теоретичній перспективі: песимістичні прогнози, оптимістичні контраргументи та одна чи дві провокації. Українське суспільство на шляху перетворень: західна інтерпретація. За ред. Пер. з англ. В. Ісаєва. Київ : Вид. дім «КМ академія», 2004. С.30-45.

7. Урри Д. Взгляд туриста и и глобализация. Массовая культура: современные западные исследований. Пер. с англ. В. В. Зверевой. Москва : Фонд научных исследований «Прагматика культуры», 2005. С. 136-152.

8. Федотова В. Г., Колпаков В. А., Федотова Н. Н. Глобальный капитализм: три великих трансформации. Москва : Культурная революция, 2008. 608 с.

9. Чорненька Н. Організація туристичної індустрії. Київ : Атіка, 2006. 264 с.

\section{References}

1. Bauman, Z. (2005). Ydentychnost' v hlobalyzyruiuschemsia myre [Ydentychnost hlobalyzyruyuschemsya in the world]. Retrieved from http://www.lovievich.ru. [in Ukrainian].

2. Chornen'ka, N. (2006) Orhanizatsiia turystychnoi industrii [Organization of the tourism industry]. Kyiv: Atika [in Ukrainian]. 
3. Held, D., MakHriu, E., Holdblatt, D., \& Perraton D. (2003). Hlobal'ni transformatsii [Global Transformation]. (V. Kurhans'kyj, B. Sikora, Trans). Kyiv: Feniks [in Ukrainian].

4. Losev, A. (1981). Dyalektyka tvorcheskoho akta (kratkyj ocherk) [Dialectics tvorcheskoho act (Brief Essay)]. Kontekst 1981. Moskva: Nauka [in Russian].

5. Malakhov, V .A. (2001). Etyka [Ethics]. Kyiv : Lybid' [in Ukrainian].

6. Markov, B. V. (1999). Khram y rynok [temple and market]. Sankt-Peterburh: Aletejia [in Russian].

7. Motyl', O. (2004). Ukraina v teoretychnij perspektyvi: pesymistychni prohnozy, optymistychni kontrarhumenty ta odna chy dvi provokatsii [Ukraine in theoretical perspective: pessimistic, optimistic counter and one or two provocations]. Ukrains'ke suspil'stvo na shliakhu peretvoren': zakhidna interpretatsiia [Ukrainian society towards change: Western interpretation]. (V. Isaieva, Ed.) Kyiv: Vyd. dim «KM akademiia» [in Ukrainian].

8. Urri, D. (2005). Vzgljad turista i i globalizacija [Sight tourist and Globalization]. Massovaja kul'tura: sovremennye zapadnye issledovanij [Popular culture: modern Western studies]. (V. V. Zverevoj, Trans). Moskva: Fond nauchnyh issledovanij «Pragmatika kul'tury» [in Russian].

9. Fedotova, V. G., Kolpakov, V. A., \& Fedotova, N. N. (2008). Global'nyj kapitalizm: tri velikih transformacii [Global Capitalism: Three Great Transformations]. Moskva: Kul'turnaja revoljucija [in Russian].

Стаття надійшла до редакції 15.01.2019 р. 